УдК 616.314.17.002.3-031.82-018.74

DOI 10.11603/2311-9624.2020.4.11719

(СЮ. Б. Різник ${ }^{1}$, С. С. Різник ${ }^{2}$

Львівський національний медичний університет імені Данила Галицького ${ }^{1}$

Львівський медичний інститут ${ }^{2}$

e-mail: yuriyriznyk@gmail.com

\title{
Дисфункція ендотелію судин пародонта при генералізованому пародонтиті на тлі цукрового діабету 2 типу
}

ІНФОРМАЦІЯ

Надійшла до редакціï/Received: 02.10.2020 p.

Ключові слова: генералізований пародонтит; цукровий діабет 2 типу; дисфункція ендотелію; ендотелін-1; нітританіон.
АНОТАЦІЯ

Резюме. Дисфункція ендотелію має важливе значення у розвитку процесів ішемізації при порушенні мікроциркуляції та характеризується порушенням ендотелійзалежної релаксації судин, підвищеною адгезивністю ендотелію і розглядається не тільки як маркер судинних порушень, але і як причина розвитку, прогресування й клінічних проявів численних захворювань.

Мета дослідження - виявити кореляцію між клінічними проявами ГП та функціональними змінами його судинної системи у хворих на Цд 2 типу за рівнями вазоконстриктора ЕT-1 і вазодилататора нітрит-аніону (метаболіту оксиду азоту) в ротовій рідині (РР). Матеріали і методи. Проведено клінічно-лабораторні дослідження 36 хворих на цукровий діабет 2 типу, в яких діагностували генералізований пародонтит, і 12 осіб без соматичної патології із клінічно інтактним пародонтом, з метою вивчення кореляції між клінічними проявами генералізованого пародонтиту на тлі цукрового діабету 2 типу та функціональними змінами його судинної системи.

Результати досліджень та їх обговорення. Результати клінічноінструментального обстеження хворих на генералізований пародонтит на тлі Цд 2 типу виявили суттєві зміни показників індексної оцінки стану тканин пародонта, які корелювали зі ступенем тяжкості, перебігом ГП та компенсацією цукрового діабету. Результати проведених клінічно-імунологічних досліджень свідчать про те, що у хворих на генералізований пародонтит на тлі цукрового діабету 2 типу спостерігається порушення ендотелійзалежної релаксації судин, що спонукає до розвитку вираженої вазоконстрикції та зниження інтенсивності локального кровотоку. Прогресування дистрофічно-запального процесу в пародонтальних тканинах під час загострення генералізованого пародонтиту в пацієнтів із цукровим діабетом супроводжується розвитком ендотеліальної дисфункції, яка характеризується підвищеним синтезом потужного вазоконстриктора ендотеліну-1 та вазодилататора нітрит-аніону.

Висновки. В результаті проведених досліджень хворих на ГП на тлі Цд 2 типу встановлено, що патологічні зміни пародонта характеризуються високими показниками гінгівальних і пародонтальних індексів, а також підвищеною концентрацією ЕТ-1 та нітританіону в РР, що знаходяться у прямій кореляційній залежності від ступеня тяжкості, перебігу ГП та стадії компенсації Цд. Визначення рівнів ЕТ-1 і похідних оксиду азоту в РP є важливими чинниками для встановлення тяжкості патологічного процесу та ефективності лікування хворих на ГП.
Вступ. Важливим досягненням у вирішенні питання патогенезу генералізованого па- родонтиту (ГП) на тлі цукрового діабету (ЦД) стало вивчення дисфункції ендотелію судин 
пародонта, що характеризується порушенням чинників вазоконстрикції і вазодилатації у судинах, підвищеною адгезивністю ендотелію і відіграє важливу роль у патогенезі діабетичної мікроангіопатії [1-4]. Особливу увагу в індукції судинних порушень приділяють ендотеліну-1 (ЕT-1) - найпотужнішому ендогенному вазоконстриктору, який має велике значення в регулюванні системного та локального тонусу судин, плинності гемомікроциркуляторного русла. Він відігріє певну роль у розвитку гіпертонічної хвороби та атеросклерозу [5-9]. Підвищений рівень циркулюючого ендотеліну-1 був виявлений у пацієнтів із Цд, а також було доведено позитивну кореляцію між рівнем ЕТ-1 плазми і мікроангіопатією у хворих із Цд 2 типу. ЕT-1 індукує зниження чутливості до інсуліну і може брати участь у розвитку метаболічного синдрому [3, 6].

Окрім своїх безпосередніх судинозвужувальних ефектів, підвищений рівень ЕТ-1 може сприяти ендотеліальній дисфункції через інгібуючу дію на оксид азоту (NO), який $€$ маркером дисфункції ендотелію (ДЕ), продукується ендотелієм, і має ангіопротекторні властивості. Оксид азоту інгібує агрегацію та адгезію тромбоцитів, є унікальним регулятором гомеостазу, який має виражені вазодилатуючі та антитромбогенні властивості [6, 10, 11]. Наявність вогнища запалення супроводжується збільшенням продукування оксиду азоту та його метаболіту нітрит-аніону в крові та ротовій рідині. Незважаючи на різноманітність досліджень функцій ендотелію в останні роки, механізм розвитку ДЕ при ГП на тлі ЦД вивчено недостатньо.

Метою дослідження було виявити кореляцію між клінічними проявами ГП та функціональними змінами його судинної системи у хворих на Цд 2 типу за рівнями вазоконстриктора ET-1 і вазодилататора нітрит-аніону (метаболіту оксиду азоту) в ротовій рідині (РP).

Матеріали і методи. Проведено клінічнолабораторні дослідження 36 хворих на Цд 2 типу у віці 40-65 років і 12 осіб без соматичної патології із клінічно інтактним пародонтом (група порівняння). Відповідно до систематики хвороб пародонта М. Ф. Данилевського у 17 хворих діагностовано ГП початкового і І ступеня, в 12 хворих - ГП ІІ ступеня, у 7 осіб - ГП III ступеня. Залежно від перебігу ГП обстежено 25 хворих на хронічний ГП, у яких Цд був у стадії компенсації, і 11 хворих на ГП у стадії загострення, в яких Цд був у стадії декомпен- сації. Тривалість Цд становила в середньому $(13,1 \pm 2,5)$ року. Найбільшу групу склали пацієнти з тривалістю Цд від 5 до 10 років (27 осіб $75 \%)$.

Для оцінки пародонтологічного статусу хворих проводили клінічні та параклінічні методи обстеження. 3 цією метою визначали ступінь запалення тканин пародонта за папілярно-маргінально-альвеолярним індексом PMA (C. Parma, 1960) та пародонтальним індексом PI (A. Russel, 1956). Індексна оцінка тканин пародонта включала також визначення спрощеного індексу гігієни ротової порожнини Гріна - Вермільйона (Oral Hygiene Index-Simlified, Green - Vermillion, 1964) та індексу кровоточивості ясен ВоР (Ainamo, Вау, 1975). Рівень деструкції кістки альвеолярних відростків визначали за допомогою ортопантомографії на внутрішньоротових періапікальних рентгенограм.

Об’єктом імунологічних досліджень була ротова рідина (РP), яку збирали ранком натще, шляхом спльовування у стерильні пробірки. Отримані субстрати центрифугували при 3000 об./хв упродовж 15 хв. Для досліджень використовували надосадову рідину, яку зберігали у морозильній камері при температурі $-70{ }^{\circ} \mathrm{C}$. Супернатанти досліджували після розморожування з використанням імуноферментних аналізаторів STAT FAX 303 plus. Концентрацію ET-1 визначали за допомогою набору реактивів Endothelin-1 «Biomedica» (Австрія).

Експрес-метод визначення нітрит-аніону (метаболіту оксиду азоту) в РP полягав у наступному: до 0,2 мл РP додавали 0,2 мл $1 \mathrm{~N}$ $\mathrm{NaOH}$ та через 10 хв перебування на льоду 0,4 мл дистильованої води і 1,2 мл 4 \% ZnSO4. Через 20 хв центрифугування при охолодженні відбирали прозорий супернатант 1,2 мл, до якого додавали 1,2 мл реактиву Гріса. Результати оцінювали на спектрофотометрі, при довжині хвилі -550 нм. Статистичне опрацювання результатів досліджень проводили за допомогою пакета прикладних програм Microsoft office Exel. Показник вірогідності оцінювали за t- критерієм Стьюдента.

Результати досліджень та їх обговорення. Результати клінічно-інструментального обстеження 36 хворих на ГП на тлі ЦД 2 типу виявили суттєві зміни показників індексної оцінки стану пародонтальних тканин, які знаходяться у прямій кореляційній залежності зі ступенем тяжкості, перебігом ГП та ступенем компенсації цД. При хронічному ГП II і III сту- 
пенів індекс PMA був у межах $35-45$ \%, тобто відповідав симптоматичному гінгівіту II ступеня тяжкості, тоді як при загостренні ГП цей індекс становив 60-69 \% (табл. 1).

Пародонтальний індекс (PI) при загостренні ГП початкового і I ступеня становив $(1,84 \pm 0,05)$ бала, тоді як при хронічному перебігу ГП $(1,25 \pm 0,05)$ бала. При III ступені цей індекс зростав у 3 рази порівняно 3 I ступенем ГП при ЦД 2 типу (табл. 1). Індекс OHI-S у хворих на ЦД 2 типу був в межах від 1,51 до 2,53 бала. При загостренні ГП індекс гігієни ротової порожнини OHI-S відповідає незадовільній її гігієні. При хронічному ГП початкового і I ступеня індекс OHI-S становив $(1,51 \pm 0,05)$ бала, що відповідає стану «задовільно», тоді як при ГП II і III ступенів у стадії загострення гігієна була незадовільною, відповідно $(2,13 \pm 0,21)$ і $(2,53 \pm 0,14)$ бала (табл. 1). Подібна закономірність спостерігалась і стосовно індексу кровоточивості ВоР (табл. 1). Глибина пародонтальних кишень (ПК) знаходилась у прямій пропорційній залежності від перебігу, тяжкості ГП та стадії компенсації цд. Так, при загостренні симптоматичного гінгівіту при III ступені глибина ПК була у 2,5 раза більшою $(6,82 \pm 0,25)$ мм, ніж при І ступені ГП $(2,95 \pm 0,12)$ мм.

У результаті проведених імунологічних досліджень встановлено, що концентрація ЕТ-1 у РР при хронічному ГП І ступеня становила $(0,74 \pm 0,05)$ фмоль/мл, що в 1,8 раза перевищувала його рівень групи порівняння $(\mathrm{p}<0,01)$ (табл. 2). Максимальна концентрація ЕТ-1 у РP визначалась у хворих на ГП ІІІ ступеня на тлі декомпенсованого цД і становила $(1,27 \pm 0,19)$ фмоль/мл, що втричі перевищувала рівень групи порівняння $(\mathrm{p}<0,001)$. Таким чином, виявляється прямий кореляційний зв'язок між рівнем ЕТ-1, ступенем тяжкості ГП (табл. 2) і ступенем компенсації цд.

таблищя 1. Індексна оцінка стану тканин пародонта у хворих на генералізований парадонтит на тлі цд 2 типу

\begin{tabular}{|l|l|c|c|c|c|}
\hline \multicolumn{2}{|c|}{ Діагноз } & PMA, $\%$ & PI, бали & OНІ-S, бали & ВоР, $\%$ \\
\hline \multicolumn{2}{|l}{ Інтактний пародонт (n=12) } & $13,7 \pm 2,8$ & $0,12 \pm 0,09$ & $0,51 \pm 0,24$ & $9,5 \pm 0,05$ \\
\hline \multirow{2}{*}{$\begin{array}{l}\text { ГП, початковий і } \\
\text { ступінь }\end{array}$} & загострення (n=9) & $52,8 \pm 3,4$ & $1,84 \pm 0,05$ & $1,75 \pm 0,08$ & $41,5 \pm 3,8^{* *}$ \\
\cline { 2 - 6 } & хронічний (n=8) & $27,5 \pm 3,12$ & $1,25 \pm 0,05$ & $1,51 \pm 0,06$ & $26,2 \pm 2,5^{* *}$ \\
\hline ГП, ІІ ступінь & загострення (n=6) & $60,9 \pm 6,2$ & $3,91 \pm 0,42^{*}$ & $2,13 \pm 0,21^{*}$ & $62,7 \pm 6,1^{* *}$ \\
\cline { 2 - 6 } & хронічний (n=6) & $35,7 \pm 1,25$ & $2,83 \pm 0,11$ & $1,72 \pm 0,15$ & $35,7 \pm 3,4^{* *}$ \\
\hline \multirow{2}{*}{ ГП, ІІІ ступінь } & загострення (n=4) & $69,3 \pm 5,2^{*}$ & $5,89 \pm 0,21^{* *}$ & $2,53 \pm 0,14^{*}$ & $88,3 \pm 5,5^{* *}$ \\
\cline { 2 - 6 } & хронічний (n=3) & $45,5 \pm 4,5^{*}$ & $4,16 \pm 0,42$ & $1,87 \pm 0,12$ & $48,6 \pm 4,5^{* *}$ \\
\hline
\end{tabular}

Примітка. p - показник вірогідності різниці порівняно з інтактним пародонтом. Вірогідність - p<0,05*, p<0,001**.

Таблиця 2. Показник рівнів ЕТ-1 та нітрит-аніону в ротовій рідині хворих на генералізований пародонтит на тлі ЦД

\begin{tabular}{|l|l|c|c|}
\hline \multicolumn{2}{|c|}{ Діагноз } & Нітрит-аніон, мкмоль/л & ЕТ-1, фмоль/мл \\
\hline \multicolumn{2}{|l|}{ Інтактний пародонт (n=12) } & $5,1 \pm 0,5$ & $0,42 \pm 0,03$ \\
\hline \multirow{2}{*}{ ГП ступочатковий і } & загострення (n=9) & $55,5 \pm 2,7$ & $0,86 \pm 0,1$ \\
& & $\mathrm{p}<0,01$ & $\mathrm{p}<0,01$ \\
\cline { 2 - 4 } & хронічний (n=8) & $50,2 \pm 3,3$ & $\mathrm{p}<0,014 \pm 0,05$ \\
\hline \multirow{2}{*}{ ГП, ІІ ступінь } & загострення $(\mathrm{n}=6)$ & $\mathrm{p}<0,01$ & $1,05 \pm 0,14$ \\
& & $75,5 \pm 3,1$ & $\mathrm{p}<0,001$ \\
\cline { 2 - 4 } & хронічний $(\mathrm{n}=6)$ & $\mathrm{p}<0,001$ & $0,92 \pm 0,1$ \\
& & $66,9 \pm 2,7$ & $\mathrm{p}<0,001$ \\
\hline \multirow{2}{*}{ ГП, ІІІ ступінь } & загострення $(\mathrm{n}=4)$ & $\mathrm{p}<0,001$ & $1,27 \pm 0,19$ \\
& & $88,7 \pm 3,8$ & $\mathrm{p}<0,001$ \\
\cline { 2 - 4 } & хронічний $(\mathrm{n}=3)$ & $\mathrm{p}<0,001$ & $1,12 \pm 0,1$ \\
& & $84,2 \pm 2,7$ & $\mathrm{p}<0,001$ \\
\hline
\end{tabular}

Примітка. р - показник вірогідності різниці порівняно з інтактним пародонтом. 
У результаті проведених досліджень встановлено, що максимальна концентрація нітрит-аніону визначалась у хворих на загострений ГП ІІІ ступеня на тлі декомпенсованого Цд і становила $(88,7 \pm 3,8)$ мкмоль/л, що у 17 разів перевищувало показники групи порівняння (табл. 2).

При хронічному ГП початкового і I ступенів на тлі компенсованого цд рівень нітрит-аніону становив $(50,2 \pm 3,3)$ мкмоль/л, що у 9,8 раза більше його рівня у групі порівняння (табл. 2).

На сучасному етапі більшість дослідників вважає генералізований пародонтит поліетіологічним захворюванням із різними механізмами патогенезу. В останні роки з'явились публікації про значення біологічно активних речовин, які продукує ендотелій для регулювання кровообігу, судинного тонусу, процесів гемостазу. Оцінка ендотеліальної дисфункції $€$ новим і перспективним напрямком у сучасній медицині. Ендотеліальна дисфункція сьогодні розглядається не тільки як маркер судинних порушень, доведено її важливе значення в ініціюванні, прогресуванні й клінічних проявах численних захворювань, зокрема ангіопатій при цукровому діабеті, артеріальній гіпертензії, серцевій недостатності, колагенозах, нирковій недостатності та інших патологічних процесах [1, 5-7, 12]. Модулюючу дію на реакцію судин ендотелій має через вазодилатаційні (оксид азоту) та вазоконстрикційні (ендотелін-1, тромбоксан-А речовини, синтез яких відбувається під дією різних гуморальних і механічних чинників.

Механізм розвитку дисфункції ендотелію при генералізованому пародонтиті та тлі цукрового діабету вивчені недостатньо. Це спонукало до необхідності вивчення цієї проблеми на сучасному методичному рівні.

Метою нашого дослідження було дослідити кореляцію між клінічними проявами генералізованого пародонтиту та функціональними змінами його судинної системи у хворих на цукровий діабет за рівнями вазоконстриктора ендотеліну-1 і вазодилататора нітрит-аніону (метаболіту оксиду азоту) в ротовій рідині.

При вивченні літературних джерел ми встановили, що більшість дослідників визначала маркери дисфункції ендотелію в плазмі крові. Ми з етичних міркувань проводили до- слідження рівнів ендотеліну-1 і нітрит-аніону в ротовій рідині хворих на цукровий діабет. Тому результати наших досліджень за рівнями ендотеліну-1 та нітрит-аніону були значно нижчими порівняно із результатами В. С. Вернигородського [1], Л. А. Могильницької та Б. М. Маньковського [12]. Хоча спостерігається синергізм, кореляційний зв'язок між нашими дослідженнями, який полягає в тому, що рівні ендотеліну-1 та нітрит-аніону зростають при прогресуванні генералізованого пародонтиту та цукрового діабету. Отже, визначення рівнів ендотеліну-1 і похідних оксиду азоту в ротовій рідині може бути діагностично важливим чинником для встановлення тяжкості патологічного процесу й ефективності лікування хворих на генералізований пародонтит.

Висновки. У результаті проведених клінічно-інструментальних досліджень хворих на ГП на тлі цд 2 типу встановлено, що патологічні зміни пародонта характеризуються високими показниками гінгівальних і пародонтальних індексів, які знаходяться у прямій кореляційній залежності від ступеня тяжкості, перебігу ГП та стадії компенсації цд. При ГП на тлі цД у судинах пародонта спостерігаються порушення ендотелійзалежної релаксації судин і підвищення адгезивності ендотелію. Це спонукає до розвитку вираженої вазоконстрикції та зниження інтенсивності локального кровообігу, що може спричинити підвищену агрегацію тромбоцитів. Наростання тяжкості процесу в пародонтальних тканинах під час загострення ГП у хворих на ЦД супроводжується розвитком ДЕ, яка проявляеться підвищеним синтезом і звільненими ендотелієм потужного вазоконстриктора ЕТ-1 і вазодилататора нітрит-аніону. Це спонукає до прогресування дистрофічно-запального процесу в тканинах пародонта. Визначення рівнів ЕT-1 та нітрит-аніону - маркерів дисфункції ендотелію, може слугувати діагностичним тестом перебігу патологічного процесу та оцінки ефективності лікування хворих на ГП.

У всіх обстежених хворих на Цд 2 типу наявна патологія пародонта, що свідчить про взаємозв'язок хвороб пародонта і цД, отже, усі хворі потребують ефективного лікування та профілактики. 


\author{
(СЮ. Б. Ризнык ${ }^{1}$, С. С. Ризнык ${ }^{2}$
}

Львовский национальный медицинский университет имени Данила Галицкого ${ }^{1}$

Львовский медицинский институт ${ }^{2}$

\title{
Дисфункция эндотелия сосудов пародонта при генерализованном пародонтите на фоне сахарного диабета 2 типа
}

Резюме. Дисфункция эндотелия имеет важное значение в развитии процессов ишемизации при нарушениях микроциркуляции и характеризуется нарушением эндотелийзависимой релаксации сосудов, повышенной адгезивностью эндотелия и рассматривается не только как маркер сосудистых нарушений, но и как причина развития многочисленных заболеваний.

Цель исследования - выявить корреляцию между клиническими проявлениями ГП и функциональными изменениями его сосудистой системы у больных Сд 2 типа по уровням вазоконстриктора ЭТ-1 и вазодилататора нитрит-аниона (метаболита оксида азота) в ротовой жидкости (РР). Материалы и методы. Проведены клинико-лабораторные исследования 36 больных сахарным диабетом 2 типа, у которых диагностировали генерализованный пародонтит, и 12 лиц без соматической патологии с клинически интактным пародонтом, с целью изучения корреляции между клиническими проявлениями генерализованного пародонтита на фоне сахарного диабета 2 типа и функциональными изменениями его сосудистой системы.

Результаты исследований и их обсуждение. Результаты клинико-инструментального обследования больных генерализованым пародонтитом на фоне сахарного диабета 2 типа обнаружили существенные изменения показателей индексной оценки состояния тканей пародонта, которые коррелируют со степенью тяжести, течением генерализованного пародонтита, и компенсацией сахарного диабета. Результаты проведенных клинико-иммунологических исследований свидетельствуют, что у больных генерализованным пародонтитом на фоне сахарного диабета 2 типа наблюдается нарушение эндотелийзависимой релаксации сосудов, что способствует развитию выраженной вазоконстрикции и снижению интенсивности локального кровотока. Нарастание тяжести дистрофически-воспалительного процесса в тканях пародонта во время обострения генерализованного пародонтита у больных сахарным диабетом сопровождается повышенным синтезом эндотелина-1 и нитрит-аниона.

Выводы. В результате проведенных исследований больных ГП на фоне Сд 2 типа установлено, что патологические изменения пародонта характеризуются высокими показателями гингивальных и пародонтальных индексов, а также повышенной концентрацией ЭТ-1 и нитрит-аниона в РР, находящихся в прямой корреляционной зависимости от степени тяжести, течения ГП и стадии компенсации СД. Определение уровней ЭТ-1 и производных оксида азота в РР являются важными факторами для установления тяжести патологического процесса и эффективности лечения больных ГП.

Ключевые слова: генерализованный пародонтит; сахарный диабет 2 типа; дисфункция эндотелия; эндотелин -1; нитрит-анион.

\author{
CY. B. Riznyk ${ }^{1}$, S. S. Riznyk ${ }^{2}$ \\ Danylo Halytskyi Lviv National Medical University ${ }^{1}$ \\ Lviv Medical Institute ${ }^{2}$
}

\section{Periodontal vascular endothelial dysfunction in generalized periodontitis on the background of type 2 diabetes mellitus}

Summary. Endothelial dysfunction is crucial in the development of ischemic processes in microcirculation disorders. It is characterized by impaired endothelium-dependent vascular relaxation, increased endothelial adhesion and is considered not only as a marker of vascular disorder, but also as a cause of development, progression, and clinical manifestations of many diseases.

The aim of the study - the correlation between the clinical manifestations of the GP and the functional changes of the third vascular system in patients with type 2 DM behind the vasoconstrictor ET-1 and the nitrite-anion (nitric oxide metabolism) vasodilator in the oral liguid.

Materials and Methods. Clinical and laboratory studies were conducted for 36 patients with type 2 diabetes mellitus, who were diagnosed with generalized periodontitis (GP) and 12 people without somatic pathology with clinically intact periodontium, to study the correlation between clinical manifestations of generalized periodontitis in the settings of type 2 diabetes mellitus and functional changes in its vascular system. 


\section{Терапевтична стоматологія}

Results and Discussion. The results of clinical and instrumental examinations of patients with generalized periodontitis on the background of type 2 diabetes revealed significant changes in the indicators of index assessment of periodontal tissues, which correlated with the severity, course of GP, and compensation of diabetes. The results of clinical and immunological studies indicate a disturbance of endothelium-dependent vascular relaxation in patients with generalized periodontitis on the background of type 2 diabetes mellitus, which leads to the development of severe vasoconstriction and reduced local blood flow. The progression of the dystrophic-inflammatory process in periodontal tissues during exacerbation of generalized periodontitis in patients with diabetes mellitus is accompanied by the development of endothelial dysfunction, which is characterized by increased synthesis of a powerful endothelin-1 vasoconstrictor and nitrite anion vasodilator. Conclusions. It was found in the result of studies of patients with GP on the background of type 2 diabetes that pathological changes of the periodontal tissues are characterized by high levels of gingival and periodontal indices and increased concentration of ET-1 and nitrite anion in the oral fluid, which are directly correlated with severity, course of GP and stage of diabetes compensation. Detection of levels of ET-1 and nitric oxide derivatives in the oral fluid are important factors in determining the severity of the pathological process and the treatment effectiveness of patients with GP.

Key words: generalized periodontitis; type 2 diabetes mellitus; endothelial dysfunction; Endothelin-1; nitrite anion.

\section{СПИСОК ЛІТЕРАТУРИ}

1. Вернигородский В. С. Эндотелиальная дисфункция при сахарном диабете / В. С. Вернигородский // Вісник Вінницького національного медичного університету. - 2004. - № 1. - С. 86-87.

2. Кравчук Н. О. Дослідження рівня ендотеліну-1 у хворих на цукровий діабет II типу та його корекція за допомогою діабетону MR / H. О. Кравчук, I. I. Алексєєва // Проблеми ендокринної патології. - 2004. № 4. - C. 3-7.

3. Kalani M. The importance of endothelin - 1 for microvascular dysfunction in diabetes / M. Kalani // Vasc. Health Risk Manag. - 2008. - Vol. 4 (5). - P. 10611068.

4. Indicators of lipid metabolism and their relation to disorders of microcirculation in diabetes mellitus / F.A.Zvershkhanovskiǔ, I. V.Zhulkevich, V.S. Danilishina, G. D. Zhulkevich // Problemy Endokrinologii. - 1987. Vol. 33 (4). - P. 15-18.

5. Гомазков О. А. Эндотелин в кардиологии: молекулярные, физиологические и патологические аспекты / О. А. Гомазков // Кардиология. - 2001. № 2. - С. 50-58.

6. Коркушко О. В. Эндотелиальная дисфункция.

\section{REFERENCES}

1. Vernigorodskiy, V.S. (2004). Endotelialnaya disfunktsiya pri sakharnom diabete [Endothelial dysfunction in diabetes mellitus]. Visnyk Vinnytskoho natsionalnoho medychnoho universytetu - Bulletin of Vinnytsia National Medical University, 1, 86-87 [in Russian].

2. Kravchuk, N.O., \& Aleksieieva, I.I. (2004). Doslidzhennia rivnia endotelinu-1 u khvorykh na tsukrovyi diabet II typu ta yoho korektsiia za dopomohoiu diabetonu MR [Study of endothelin-1 levels in patients with type II diabetes mellitus and its correction with MR diabetes mellitus]. Problemy endokrynnoi patolohii - Problems of Endocrine Pathology, 4, 3-7 [in Ukrainian].

3. Kalani, M. (2008). The importans of endothelin - 1
Клинические аспекты, проблемы / О. В. Коркушко, В. Ю. Лишневская // Кровообіг і гемостаз. - 2003. № 2. - С. 4-15.

7. Малая Л. Т. Эндотелиальная дисфункция при патологии сердечно-сосудистой системы / Л. Т. Малая, А. Н. Корж. - Х. : Торсинг, 2000. - 432 с.

8. Сагач В. Ф. Ендотелін і серцево-судинна система / В. Ф. Сагач // Фізіологічний журнал. - 2008. - Т. 44, № 1-2. - C. 103-109.

9. Cai H. Endothelial dysfunction in cardiovascular diseases: the role of oxidant stress / H. Cai, D. G. Harrison // Circ. Res. - 2000. - Vol. 87. - P. 840-804.

10. Зотова И. В. Синтез оксида азота и развитие атеросклероза / И. В. Зотова, Д. А. Затейщиков, Б. А. Сидоренко // Кардиология. - 2002. - № 4. - С. 58-69.

11. Halcox J. Endothelial dysfunction and prognosis circulation / J. Halcox // Circulation. - 2002. - № 106. P. 653-659.

12. Могильницька Л. М. Ендотеліальна дисфункція у хворих на цукровий діабет 2 типу / Л. М. Могильницька, Б. М. Маньковський // Ендокринологія. 2001. - T. 6 (1). - C. 95-106.

for microvascular dysfunction in diabetes. Vasc. Health Risk Manag., 4 (5), 1061-1068.

4. Zvershkhanovskiı̆, F.A., Zhulkevich, I.V., Danilishina, V.S., \& Zhulkevich, G.D. (1987). Indicators of lipid metabolism and their relation to disorders of microcirculation in diabetes mellitus. Problemy Endokrinologii, 33 (4), 15-18.

5. Gomazkov, O.A. (2001). Endotelin v kardiologii: molekulyarnyye, fiziologicheskiye i patologicheskiye aspekty [Endothelin in cardiology: molecular, physiological and pathological aspects]. Kardiologiya - Cardiology, 2, 50-58 [in Russian].

6. Korkushko, O.V., \& Lishnevskaya, V.Yu. (2003). En- 
dotelialnaya disfunktsiya. Klinicheskiye aspekty, problemy [Endothelial dysfunction. Clinical aspects, problems]. Krovoobih $i$ hemostaz - Blood Circulation and Hemostasis, 2, 4-15 [in Russian].

7. Malaya, L.T., \& Korzh, A.N. (2000). Endotelialnaya disfunktsiya pri patologii serdechno-sosudistoy sistemy [Endothelial dysfunction in pathology of the cardiovascular system]. Kharkiv: Torsing [in Russian].

8. Sahach, V.F. (2008). Endotelin i sertsevo-sudynna systema [Endothelin and the cardiovascular system]. Fiziolohichnyi zhurnal - Physiological Journal, 44 (1-2), 103-109 [in Ukrainian].
9. Cai, H. (2000). Endothelial dysfunction in cardiovascular diseases - the role of oxidant stress. Circ. Res., 87, 840-844.

10. Zotova, I.V., Zatejshhikov, D.A., \& Sidorenko, B.A. (2002). Sintez oksida azota i razvitie ateroskleroza. Kardiologiya - Cardiology., 4, 58-69 [in Russian].

11. Halcox, J. (2002). Endothelial dysfunction and prognosis circulation. Circulation, 106, 653-659.

12. Mohylnytska, L.M., \& Mankovskyi, B.M. (2001). Endotelialna dysfunktsiia u khvorykh na tsukrovyi diabet 2 typu [Endothelial dysfunction in patients with type 2 diabetes]. Endokrynolohiia - Endocrinology, 6 (1), 95-106 [in Ukrainian]. 